\title{
One Health and cancer: A comparative study of human and canine cancers in Nairobi
}

\author{
Nyariaro Kelvin Momanyi ${ }^{1,3}$, Rugutt Anne Korir ${ }^{2}$ and Riungu Erastus Mutiga ${ }^{1}$
}

1. Department of Clinical Studies, Faculty of Veterinary Medicine, University of Nairobi, Kenya; 2. Cancer Registry Unit, Centre for Clinical Research, Kenya Medical Research Institute, Kenya; 3. Royal (Dick) School of Veterinary Studies and The Roslin Institute, University of Edinburgh, Roslin, UK.

Corresponding author: Nyariaro Kelvin Momanyi, e-mail: momanyink@gmail.com, RAK: annkorir@yahoo.com, REM: mutigar@yahoo.com

Received: 06-07-2016, Accepted: 21-10-2016, Published online: 19-11-2016

doi: $10.14202 / \mathrm{IJOH} .2016 .42-57$ How to cite this article: Momanyi NK, Korir RA, Mutiga RE. One Health and cancer: A comparative study of human and canine cancers in Nairobi. Int J One Health 2016;2:42-57.

\begin{abstract}
Aim: Recent trends in comparative animal and human research inform us that collaborative research plays a key role in deciphering and solving cancer challenges. Globally, cancer is a devastating diagnosis with an increasing burden in both humans and dogs and ranks as the number three killer among humans in Kenya. This study aimed to provide comparative information on cancers affecting humans and dogs in Nairobi, Kenya.

Materials and Methods: Dog data collection was by cancer case finding from five veterinary clinics and two diagnostic laboratories, whereas the human dataset was from the Nairobi Cancer Registry covering the period 2002-2012. The analysis was achieved using IBM SPSS Statistics ${ }^{\circledR}$ v.20 (Dog data) and CanReg5 (human data). The human population was estimated from the Kenya National Census, whereas the dog population was estimated from the human using a human:dog ratio of 4.1:1.

Results: A total of 15,558 human and 367 dog cancer cases were identified. In humans, females had higher cancer cases 8993 (an age-standardized rate of 179.3 per 100,000) compared to 6565 in males $(122.1$ per 100,000). This order was reversed in dogs where males had higher cases $198(14.9$ per 100,000) compared to $169(17.5$ per 100,000) in females. The incident cancer cases increased over the 11-year study period in both species. Common cancers affecting both humans and dogs were: Prostate $(30.4,0.8)$, the respiratory tract $(8.3,1.3)$, lymphoma $(5.6,1.4)$, and liver and biliary tract $(6.3,0.5)$, whereas, in females, they were: Breast $(44.5,3.6)$, lip, oral cavity, and pharynx $(8.8,0.6)$, liver and biliary tract $(6.5,1.2)$, and lymphoma (6.0, 0.6), respectively, per 100,000.

Conclusion: The commonality of some of the cancers in both humans and dogs fortifies that it may be possible to use dogs as models and sentinels in studying human cancers in Kenya and Africa. We further infer that developing joint animalhuman cancer registries and integrated cancer surveillance systems may lead to accelerated detection of the risks of cancer in Africa.
\end{abstract}

Keywords: Africa, cancer, cancer registry, comparative oncology, Kenya, Nairobi, One Health.

\section{Introduction}

\section{One Health and cancer}

The study of cancer through comparative oncology, in recent times, has provided invaluable insights on how the pet-dog is not only man's companion but also plays an integral role in improving human health and well-being [1,2]. More importantly, reiterating the added value of One Health [3] by acting or having the potential to act as sentinels (early warning systems) and models for studying, early diagnosis and treatment of human cancer and possibly other animals as well.

\section{Cancer registries}

Cancer registries play an important role of facilitating early detection, prevention, treatment, and care

Copyright: Momanyi, et al. This article is an open access article distributed under the terms of the Creative Commons Attribution 4.0 International License (http://creativecommons.org/licenses/ by/4.0/), which permits unrestricted use, distribution, and reproduction in any medium, provided you give appropriate credit to the original author(s) and the source, provide a link to the Creative Commons license, and indicate if changes were made. The Creative Commons Public Domain Dedication waiver (http:// creativecommons.org/ publicdomain/zero/1.0/) applies to the data made available in this article, unless otherwise stated. of cancer patients. In Kenya, there are two human population-based cancer registries: Geographical positioned in Nairobi and Eldoret counties, three hospital-based registries, and three other registries are in their early stages of development. On $10^{\text {th }}$ February 2016, the Kenya National Cancer Registry Programme was launched [4]. However, there is no animal cancer registry in the country.

\section{The burden of cancer}

Worldwide, cancer continues to torment man [5] and dog [6-8] alike, with the global burden increasing in both species. Cancer is among the four noncommunicable diseases (NCDs) responsible for $82 \%$ deaths attributable to NCDs, with three quarters of these occurring in low- and middle-income countries [9].

In Kenya, cancer ranks as the number three cause of mortality among humans, after infectious diseases and cardiovascular diseases, with the number of cancer cases projected to nearly double by 2030 [10]. This has and will continue to escalate the "double burden" of disease, with an accompanying dual effect of not only straining existing health-care systems $[5,10]$ 
but also causing loss of income to already poor families and posing cumulative economic losses. The challenge of addressing cancer in Kenya has been attributed to several technical, economic, infrastructural, and social factors [11]. The burden of cancer among animals, in this case pet-dogs, is unknown in this study setting; but, there is a general observation from the practicing clinicians that cancer cases among pet-dogs are on the rise.

\section{Are dogs' better models and sentinels for human cancers?}

The dog is of special interest compared to other laboratory [12] and domestic animals in studying human cancer because: It naturally and increasingly develops spontaneous cancer similar to humans [7], which could be as a result of the increasing "humandog bond" which increases their exposure to similar risk factors and environmental carcinogens [13]. Moreover, the dog is phylogenetically closely related to man [14]; this is supported by the fact that approximately all the 19,000 genes identified in the dog match to a similar gene in the human genome [15].

Several studies have documented that pet-dogs respond to a number of environmental carcinogens, similar to the way humans do [16-20]. For instance, the association between industrial activity and consequent bladder cancer has been established [17], with the dog having a shorter latent period of bladder cancer (10 years), as compared to man (20 years) [14]. Thus, humans and dogs do develop similar cancers when exposed to similar risk factors or carcinogens, and by inference, monitoring the health of pet-dogs (and potentially other animals as well) will aid early identification and correlation between exposure to environmental contaminants and cancer in humans [21].

\section{The aim of the study}

In Kenya, the comparative aspect of studying cancers in humans and animals at the same time has not been explored. There also lacks a system for collecting population data on animal cancers similar to the human cancer registries. The objective of the study was, therefore, to determine the most common cancers affecting humans and dogs by age and gender in Nairobi area so as to determine the potential of using dogs as models and sentinels for human cancers. We presume the results to catalyze future research ventures for comparison with other populations within and elsewhere and to complement the current national and global efforts geared toward cancer prevention and control.

\section{Materials and Methods}

\section{Ethical clearance and approval}

Approval and an introductory letter seeking permission to access data from the human cancer registry, veterinary clinics, and laboratories was issued by the Faculty of Veterinary Medicine, University of Nairobi dated $24^{\text {th }}$ January 2013. For the human data, being secondary data, the corresponding scientific and ethical approvals are described $[22,23]$.

\section{Study area}

Nairobi County is the primary capital city of Kenya with a population of $3,138,369(1,605,230$ males and 1,533,139 females) based on the 2009 census [24]. It has a fairly good representation of the population and ethnic groups in Kenya. Pet animal population and structure are not available for Nairobi County, but it is home to a large number of veterinary practices and with the highest population of dogs kept as pet-dogs.

\section{Human data methodology}

The human data methodologies detailing on data collection, data variables, sources of information, data management, computer applications, coding, and classification have been described in an earlier report of 2006 by the Kenya Medical Research Institute [22] and a recent publication by Korir et al. [23]. The following sections will dwell on the dog methodologies.

\section{Tumor data sources}

Dog datasets were actively extracted from seven institutions within Nairobi County, of which five were veterinary clinics and two were reference veterinary diagnostic laboratories. The dataset comprised five sets of diagnostic records from necropsy/postmortem, laboratory (cytology and histology), clinical investigation (radiography), medical records, and index cards mentioning cancer as the contributory cause of morbidity or mortality, spanning from the year 2002 to 2012 . However, only one veterinary clinic had a computer-based disease index system. In all cases, the clinic and laboratory personnel were involved to provide the required information.

\section{Data variables}

Dog data were keyed into a preconfigured Microsoft Access $2013^{\circledR}$ database with the number of assessment variables used based on the standards provided by the International Agency for Research on Cancer as outlined by MacLennan [25] but with modifications to fit the veterinary case records and for comparison with the human records. The variables included were: The patient details (Unique ID, breed, sex, and age), the tumor details (date of diagnosis, entered as year only), the basis of diagnosis, topography (first occurrence only), morphology (based on histology/cytology), the source of information (entered as name of clinic), mode of treatment, and patient status (entered as alive or dead, as at date of data extraction).

\section{Data preparation}

Dog datasets were exported from the Microsoft Access $2013^{\circledR}$ database into IBM SPSS v20. Before exporting each data, variable was coded separately (Table-1).

\section{Data collection}

Human and dog data collection was by desk review through scheduled visits to veterinary clinics, laboratories, and the human cancer registry between 
Table-1: Dog dataset as coded in IBM SPSS v. 20.

\begin{tabular}{|c|c|c|c|c|}
\hline Variable name & Type & Measure & Label & Values \\
\hline Unique ID & Numeric & Scale & Unique patient identifier & Incremental by 1 from 1000 \\
\hline Breed & String & Nominal & Breed of dog & $\begin{array}{l}\text { Based on the } 22 \text { breeds of dogs } \\
\text { identified (coded } 00-21,99 \text { ) }\end{array}$ \\
\hline Sex & Numeric & Scale & Sex of dog & $0=$ Male, $1=$ Female \\
\hline Age & Numeric & Scale & Age of dog & Value entered as recorded \\
\hline Status & Numeric & Nominal & Status of dog on data abstraction & $0=$ Dead, $1=$ Alive, $9=$ Unknown \\
\hline Incidence & Date & Scale & Date of first registration of case & Value entered as recorded \\
\hline Topography & String & Nominal & 3-digit code of the tumor site & $\begin{array}{l}\text { Values coded based on the online } \\
\text { ICD-0-3 [57] and data available }\end{array}$ \\
\hline Morphology & Numeric & Nominal & 4-digit code of the tumor morphology & $\begin{array}{l}\text { Values coded based on the online } \\
\text { ICD-0-3 [57] and data available }\end{array}$ \\
\hline Behavior & Numeric & Nominal & Behavior of tumor & $\begin{array}{l}0=\text { Benign, } 1=\text { Uncertain, } 2=\text { In situ, } \\
3=\text { Malignant }\end{array}$ \\
\hline Diagnosis & Numeric & Nominal & Basis of diagnosis of tumor & $\begin{array}{l}0=\text { Necropsy, } 1=\text { Clinical only, } 2=\text { Clinical } \\
\text { investigation, } 3=\text { Surgery } / \text { Autopsy, } \\
4=\text { Laboratory tests, } 5=\text { Cytology, } \\
6=\text { Histology primary }\end{array}$ \\
\hline Treatment & Numeric & Nominal & Mode of treatment & $\begin{array}{l}0=\text { Medical only, } 1=\text { Surgery, } 2=\text { None, } \\
3=\text { Unknown, } 4=\text { Euthanasia }\end{array}$ \\
\hline Facility & Numeric & Nominal & The source name of data & Each facility coded individually 0-6 \\
\hline
\end{tabular}

August 2013 and April 2014. The dog data were entered directly into the preconfigured Microsoft Access $2013^{\circledR}$ database, whereas the human data were retrieved and downloaded from the Canreg5 database as a tab-separated values file format.

\section{Population data}

Human annual intercensal estimates were projected using annual growth rates for the 5-year age group and for each gender based on 1999 [26] and 2009 [24] census data for Nairobi County (Table-2). Since the Nairobi County dog population and structure is not known, the corresponding total dog population at each 5-year age group was calculated using the ratio of humans to dogs as 4.1:1 [27]. The corresponding dog numbers for each gender were calculated using the dog male:female ratio of 1.4:1 [27]. Based on the 11-year (2002-2012) population estimates, the calculated Nairobi County annual average human population was 2,991,704 (1,506,182 males and 1,406,159 females) and the dogs as 729,605 (425,603 males, 304,002 females) are shown in Figure-1 for the human and dog population pyramids.

\section{Data analysis}

Results are presented as the number of cancer cases registered, crude, and age-standardized incidence rates, for the study period (2002-2012). The crude, all ages rate per 100,000 was calculated by dividing the total number of cases per site by the total number of person/dog-years of observation and multiplying the result by 100,000 . The age-specific rate for each age group was calculated as a rate per 100,000 by dividing the number of cases in the age group by the corresponding person/dog-years of observation and multiplying the result by 100,000 .

Age-standardized rates (ASRs) per 100,000 were calculated by the direct method using the World Standard Population (for human) and using a known and published age structure for the dog [28] as an external standard but with modifications to fit study age groupings (Table-3). The cancer cases of unknown age were further included in the determination of ASR by multiplying with a correction factor. 95\% confidence intervals for the ASR were also calculated. All calculations described above were done as per guidelines by Boyle and Parkin [29].

\section{Results}

\section{Dog and human datasets}

During the 11-year period (2002-2012) under review, a total of 15,558 human cancer cases (age-standardized incidence rate of 137.4 per 100,000) were retrieved from the human cancer CanReg5 database, consisting of $6565(42.2 \%)$ male (ASR of 122.1 per $100,000)$ and $8993(57.8 \%)$ female cancer cases (ASR of 179.3 per 100,000). In dogs, 367 cancer cases (ASR of 16.0 per 100,000) were retrieved, of which $198(54.0 \%)$ were males (ASR of 14.9 per 100,000$)$ and $169(46.0 \%)$ female cancer cases (ASR of 17.5 per 100,000) shown in Table-4 for a detailed record of the ASRs for each topographical site and species and their corresponding $95 \%$ confidence intervals.

\section{Trend of cancer cases}

The number of cancer cases increased progressively over the study period in both humans and dogs as shown in Figure-2. Whereas this was generally true, the spontaneous decrease in the number of incident cases was observed in the years 2007 and 2009 in both humans and dogs.

\section{Incidence of the top 10 cancers by topography affect- ing both humans and dogs}

The common cancers affecting both male humans and dogs (among the top 10 cancers) were: Prostate (ASR of 30.4, 0.8 per 100,000), respiratory tract (ASR of $8.3,1.3$ per 100,000), lymphoma (ASR of 5.6, 1.4 per 100,000), and liver and biliary tract (ASR of 6.3, 
0.5 per 100,000), respectively. The common cancers affecting both female humans and dogs (among the top 10 cancers) were: Breast (ASR of 44.5, 3.6 per 100,000 ), lip, oral cavity, and pharynx (ASR of 8.8, 0.6 per 100,000), liver and biliary tract (ASR of 6.5 ,

Table-2: Annual growth rates for the 5-year age group and for each gender.

\begin{tabular}{lcc}
\hline Age group & \multicolumn{2}{c}{ Annual growth rates } \\
\cline { 2 - 3 } & Male (\%) & Females (\%) \\
\hline $0-4$ & 4.1 & 4.0 \\
$5-9$ & 4.8 & 4.7 \\
$10-14$ & 4.1 & 3.4 \\
$15-19$ & 2.3 & 2.1 \\
$20-24$ & 2.1 & 4.4 \\
$25-29$ & 2.9 & 5.2 \\
$30-34$ & 3.7 & 5.8 \\
$35-39$ & 4.0 & 5.6 \\
$40-44$ & 3.9 & 5.7 \\
$45-49$ & 4.2 & 6.2 \\
$50-54$ & 2.8 & 5.3 \\
$55-59$ & 5.4 & 7.0 \\
$60-64$ & 5.3 & 6.2 \\
$65-69$ & 4.2 & 5.4 \\
$70-74$ & 2.9 & 3.4 \\
$75+$ & 2.5 & 4.7 \\
\hline
\end{tabular}

1.2 per 100,000), and lymphoma (ASR of 6.0, 0.6 per 100,000), respectively (Figure-3).

Cancer cases and age-specific incidence per age group in humans and dogs

The number of cancer cases and age-specific rates per 100,000 in both humans and dogs generally increased with advancing age. The highest number of cancer cases affected humans of 40-44 age-group (but the highest age-specific rate was at 70-74 age group), whereas, in dogs, the highest cancer cases affected the 11-12 age-group (but the highest age-specific rate was at 15+ age group). By gender, most cancer cases in female humans and dogs were recorded in (40-44; 11-12) and (75+; 11-12) age groups, respectively, whereas, in male, humans and dogs they were recorded in $(75+; 15+)$ age-groups, respectively (Table-5).

\section{Breed and cancer distribution}

The dataset included 23 different dog breeds (Supplementary Material-1). Of the $23.7 \%$ crossbreeds, 6.9\% were between a German Shepherd Dog (GSD) and another known breed, $10.3 \%$ were crosses of other known breeds, and $82.8 \%$ were crosses of other unknown/unrecorded breeds, simply indicated as "cross" in the records. It was evident that

Table-3: Deriving the dog standard population using a known standard population published by Thrusfield [28].

\begin{tabular}{|c|c|c|c|c|c|c|c|c|c|c|c|}
\hline $\begin{array}{l}\text { Age } \\
\text { interval } \\
(\text { years) }\end{array}$ & Male & Female $^{c}$ & Total $^{d}$ & $\begin{array}{c}\% \\
\text { Male }\end{array}$ & $\begin{array}{c}\% \\
\text { Female }\end{array}$ & $\begin{array}{c}\% \\
\text { Totalg }\end{array}$ & Male $^{h}$ & Female $^{i}$ & Totalj ${ }^{j}$ & $\begin{array}{c}\text { Age } \\
\text { classk }\end{array}$ & $\begin{array}{c}\text { Dog } \\
\text { standard } \\
\text { population' }\end{array}$ \\
\hline$<1$ & 378,000 & 365,000 & 743,000 & 12 & 12 & 11.6 & 11,732 & 11,521 & 11,628 & $0-2 \mathrm{mo}$ & 2907 \\
\hline$<1-\leq 2$ & 433,000 & 365,000 & 798,000 & 13 & 12 & 12.5 & 13,439 & 11,521 & 12,488 & 3-5 mo & 2907 \\
\hline$<2-\leq 3$ & 378,000 & 365,000 & 743,000 & 12 & 12 & 11.6 & 11,732 & 11,521 & 11,628 & $6-8 \mathrm{mo}$ & 2907 \\
\hline$<3-\leq 4$ & 287,000 & 320,000 & 607,000 & 9 & 10 & 9.5 & 8908 & 10,101 & 9499 & 9-11 mo & 2907 \\
\hline$<4-\leq 5$ & 287,000 & 279,000 & 566,000 & 9 & 9 & 8.9 & 8908 & 8807 & 8858 & $1-2$ & 12,488 \\
\hline$<5-\leq 6$ & 239,000 & 238,000 & 477,000 & 7 & 8 & 7.5 & 7418 & 7513 & 7465 & 3 & 11,628 \\
\hline$<6-\leq 8$ & 416,000 & 447,000 & 863,000 & 13 & 14 & 13.5 & 12,911 & 14,110 & 13,505 & 4 & 9499 \\
\hline$<8-\leq 10$ & 323,000 & 323,000 & 646,000 & 10 & 10 & 10.1 & 10,025 & 10,196 & 10,110 & 5 & 8858 \\
\hline$<10-\leq 12$ & 220,000 & 244,000 & 464,000 & 7 & 8 & 7.3 & 6828 & 7702 & 7261 & $6-7$ & 7465 \\
\hline$<12-\leq 14$ & 174,000 & 152,000 & 326,000 & 5 & 5 & 5.1 & 5400 & 4798 & 5102 & 8 & 13,505 \\
\hline \multirow[t]{7}{*}{$>14$} & 87,000 & 70,000 & 157,000 & 3 & 2 & 2.5 & 2700 & 2210 & 2457 & 9 & 5055 \\
\hline & $3,222,000$ & $3,168,000$ & $6,390,000$ & 100 & 100 & 100.0 & 100,000 & 100,000 & 100,000 & 10 & 5055 \\
\hline & & & & & & & & & & $11-12$ & 7261 \\
\hline & & & & & & & & & & 13 & 5102 \\
\hline & & & & & & & & & & 14 & 1228 \\
\hline & & & & & & & & & & $15+$ & 1228 \\
\hline & & & & & & & & & & Total & 100,000 \\
\hline
\end{tabular}

${ }^{a}$ Age intervals as described by Thrusfield [28], bNumber of males per age intervals as described by Thrusfield [28], cNumber of females per age intervals as described by Thrusfield [28], dTotal number of dogs per age intervals as described by Thrusfield [28], e Calculated $\%=$ Number of males in class interval divided by total number of males

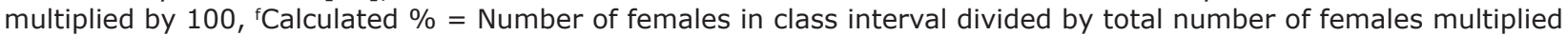
by $100,{ }^{9}$ Calculated $\%=$ Total number of dogs in class interval divided by summed total number of dogs multiplied by 100 , hWeighted number for male dogs = Value in column (b) multiplied value in column (e) for each class, 'Weighted number for male dogs = Value in column (c) multiplied value in column (i) for each class, ${ }^{j}$ Weighted number for male dogs = Value in column (d) multiplied value in column $(\mathrm{g})$ for each class, ${ }^{k}$ The 16 age groupings as per the current study to be comparable to the human 16 age groupings, 'Equally distributed from the values in column ( $\mathrm{j}$ ) and in reference to the age intervals in column (a) 


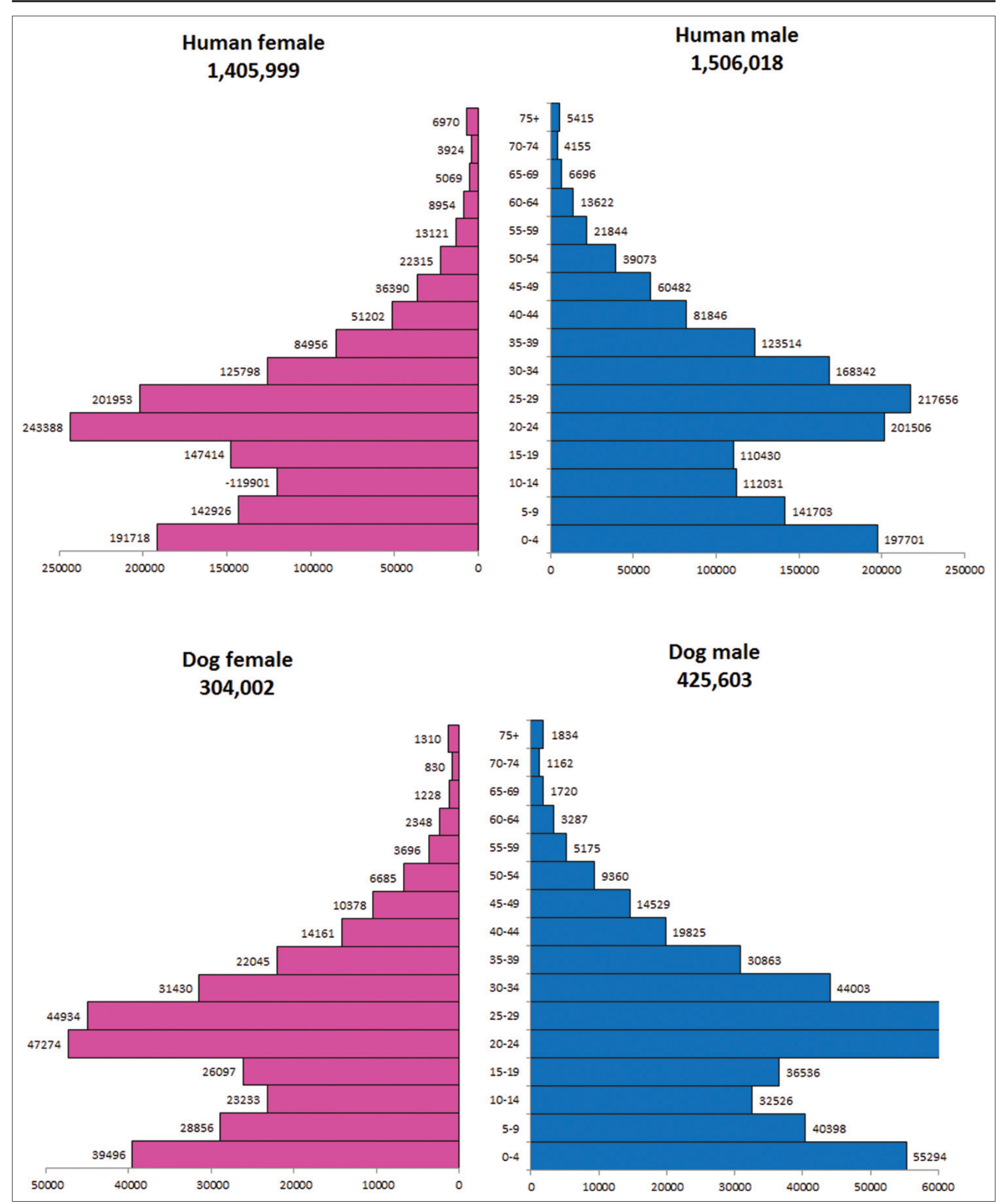

Figure-1: Composition by sex and 5-year age group of the average population for humans and dogs in Nairobi, (2002-2012).

common cancers affecting the top breeds in Nairobi were breast and skin cancers, of which they affected at a higher proportion, the German shepherd breed (breast - 3.0\%), and the crossbreeds (skin - 2.2\%).

\section{The distribution of the most common morphological} diagnoses and staging

The common individual morphological diagnoses in humans and dogs were neoplasm, malignant-8000 (14.3\%, 44.4\%), squamous cell carcinoma, NOS-8070 (19.5\%, 6.5\%), adenocarcinoma, NOS-8140 (13.8\%, 4.6\%), and malignant lymphoma, NOS-9591 (1.3\%, 8.4\%), respectively (Figure-4).

The staging distribution of human cancers was as follows: Unknown stage $(88.7 \%)$, Stage III $(2.5 \%)$, Stage IV (2.3\%), Stage II (2.1\%), and Stage I $(0.9 \%)$, excluding the invalid codes $(3.6 \%)$, whereas, 


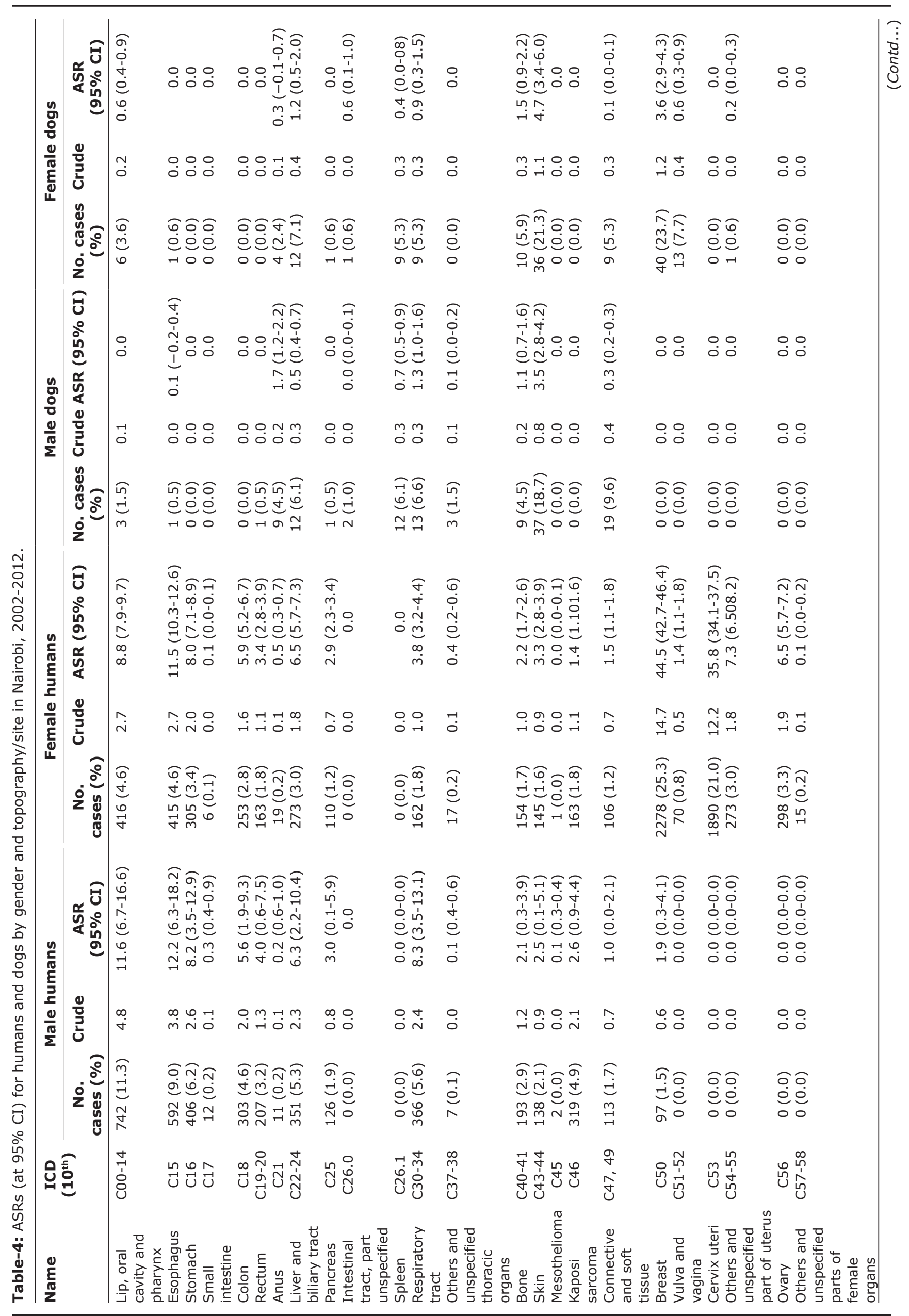




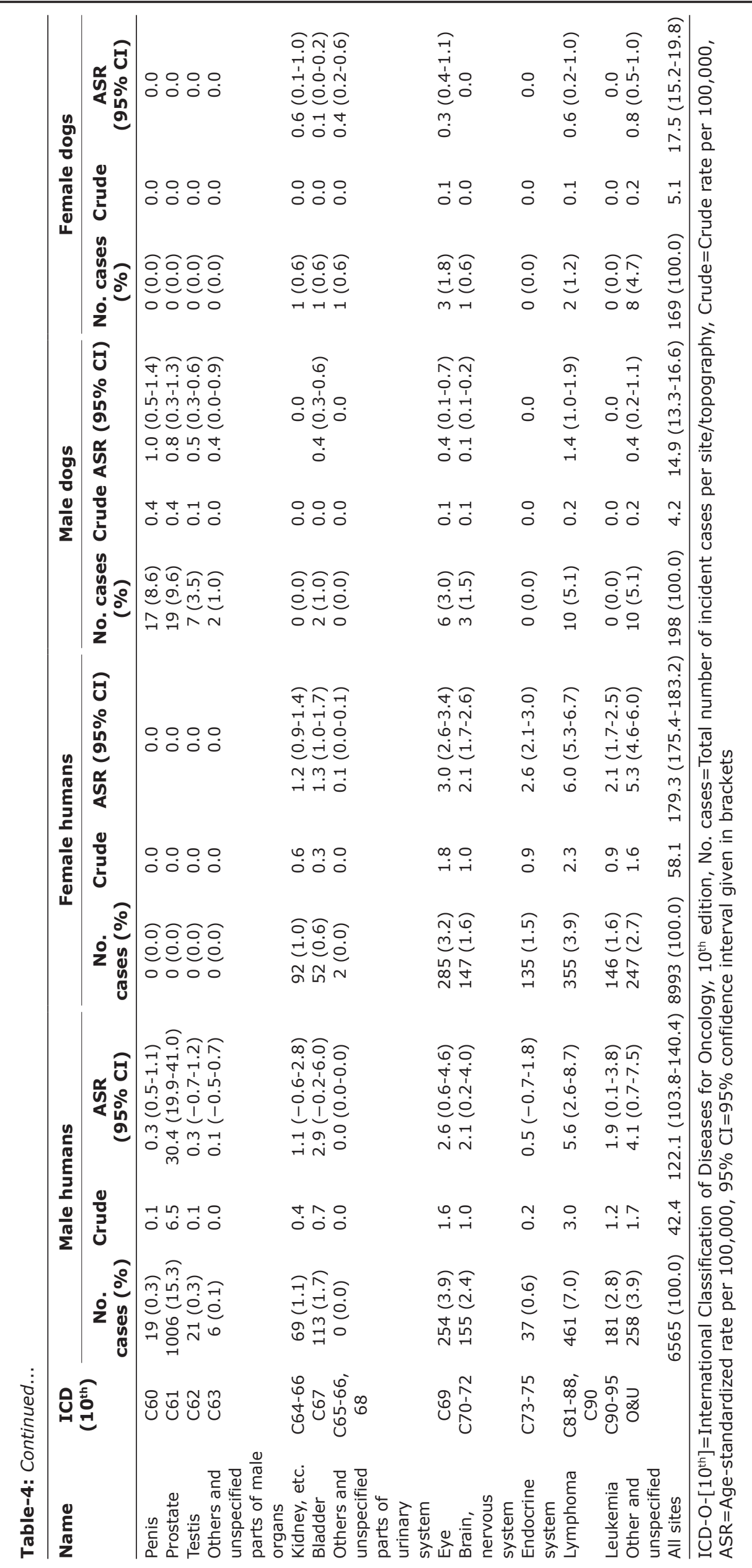




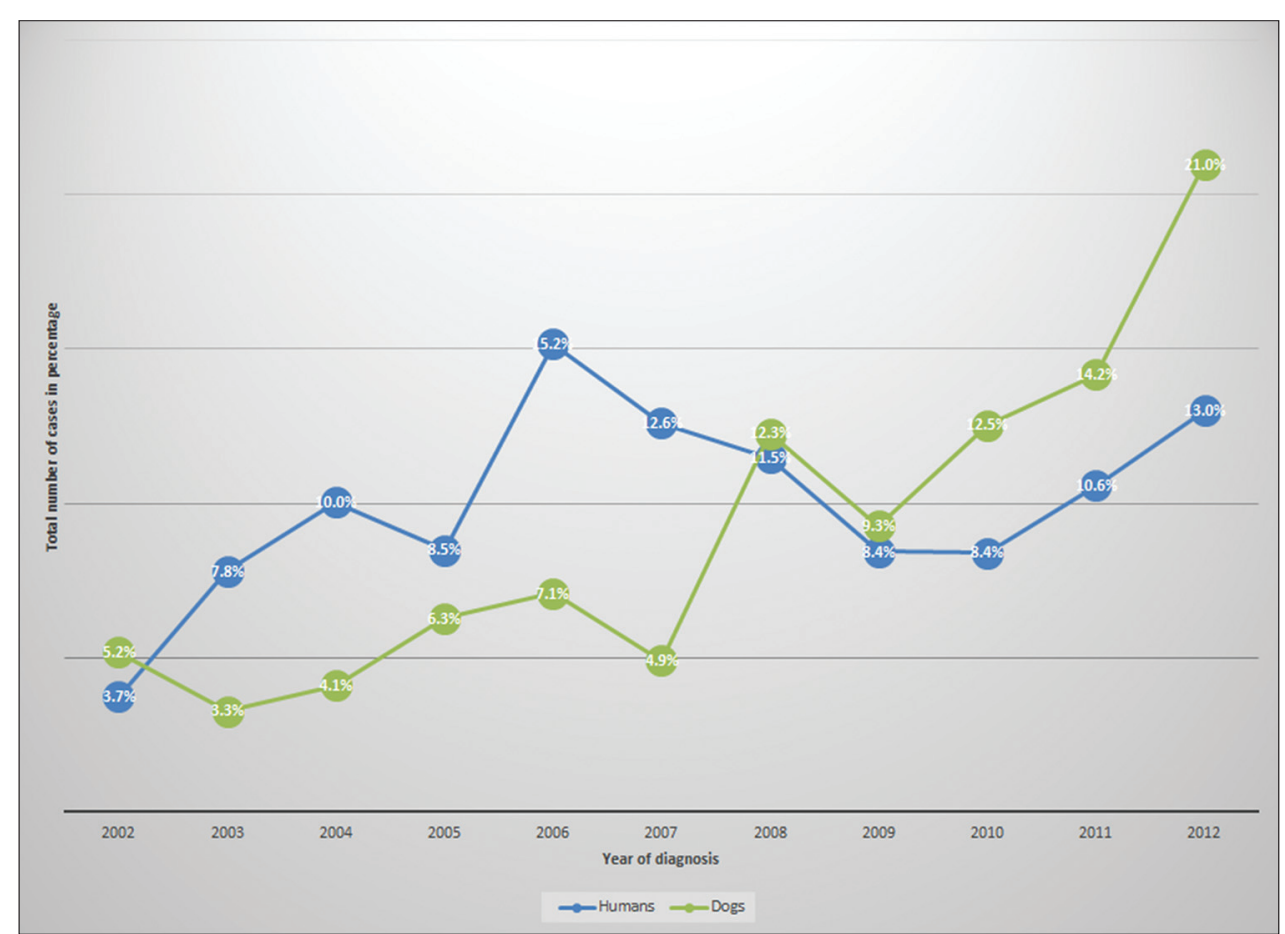

Figure-2: Trend of incident cancer cases in human and dogs in Nairobi (2002-2012).

Table-5: Number of cancer cases and age-specific rates per age group in humans and dogs.

\begin{tabular}{|c|c|c|c|c|c|c|c|c|}
\hline \multirow{2}{*}{$\begin{array}{l}\text { Human } \\
\text { years }\end{array}$} & \multirow[t]{2}{*}{ Dog years* } & \multicolumn{3}{|c|}{ Human $(\mathrm{n}=15,542) * * *$} & \multicolumn{3}{|c|}{$\operatorname{Dog}(\mathrm{n}=181) * * *$} & \multirow[t]{2}{*}{ Event** } \\
\hline & & Male & Female & Total & Male & Female & Total & \\
\hline $0-4$ & $0-2$ months & $129(5.9)$ & $115(5.5)$ & $244(5.7)$ & $0(0.0)$ & $0(0.0)$ & $0(0.0)$ & \\
\hline $5-9$ & 3-5 months & $135(8.7)$ & $73(4.6)$ & $208(6.7)$ & $0(0.0)$ & $0(0.0)$ & $0(0.0)$ & \\
\hline $10-14$ & 6-9 months & $139(11.3)$ & 99 (7.5) & $238(9.5)$ & $0(0.0)$ & $0(0.0)$ & $0(0.0)$ & $\begin{array}{l}\text { Puberty range in } \\
\text { most women and } \\
\text { bitches }\end{array}$ \\
\hline $15-19$ & $10-11$ months & $166(13.7)$ & $135(8.3)$ & $301(10.7)$ & $0(0.0)$ & $0(0.0)$ & $0(0.0)$ & \\
\hline $20-24$ & $1-2$ & $204(9.2)$ & $238(8.9)$ & $442(8.6)$ & $3(0.4)$ & $6(1.2)$ & $9(0.7)$ & \\
\hline $25-29$ & $3-4$ & $241(10.1)$ & $422(19.0)$ & $663(13.6)$ & $3(0.4)$ & $1(0.2)$ & $4(0.3)$ & \\
\hline $30-34$ & $4-5$ & $347(18.7)$ & $685(49.5)$ & $1032(30.3)$ & $6(1.2)$ & $4(1.2)$ & $10(1.2)$ & \\
\hline $35-39$ & $5-6$ & $410(30.2)$ & $924(98.9)$ & $1334(55.9)$ & $5(1.5)$ & $5(2.1)$ & $10(1.7)$ & \\
\hline $40-44$ & $6-7$ & $560(62.2)$ & $1124(199.6)$ & $1684(109.9)$ & $12(5.5)$ & $5(3.2)$ & $17(4.5)$ & $\begin{array}{l}\text { The start of } \\
\text { increased cancer } \\
\text { of all types in } \\
\text { both species }\end{array}$ \\
\hline $45-49$ & $8-9$ & $587(88.2)$ & $1082(270.3)$ & $1669(148.6)$ & $8(5.0)$ & $5(4.4)$ & $13(4.7)$ & \\
\hline $50-54$ & $9-10$ & $613(142.6)$ & $981(399.6)$ & $1594(220.3)$ & $4(3.9)$ & $8(10.9)$ & $12(6.8)$ & \\
\hline $55-59$ & $10-11$ & $546(227.2)$ & 851 (589.6) & $1397(349.2)$ & $16(28.1)$ & $12(29.5)$ & $28(28.7)$ & \\
\hline $60-64$ & $11-12$ & $662(441.8)$ & $742(753.3)$ & $1404(552.4)$ & $23(63.6)$ & $15(58.1)$ & $38(61.3)$ & \\
\hline $65-69$ & $13-14$ & $571(775.2)$ & $542(972.1)$ & $1113(837.2)$ & $5(26.4)$ & $7(51.8)$ & $12(37.0)$ & \\
\hline $70-74$ & $14-15$ & $547(1196.8)$ & $448(1038.0)$ & 995 (1107.7) & $4(31.3)$ & $2(21.9)$ & $6(27.4)$ & \\
\hline $75+$ & $15+$ & $702(1178.6)$ & $522(680.8)$ & $1224(863.1)$ & $8(39.6)$ & $14(97.1)$ & $22(63.6)$ & $\begin{array}{l}\text { A reasonable } \\
\text { equivalent of } \\
\text { an upper age } \\
\text { extreme for both } \\
\text { species }\end{array}$ \\
\hline
\end{tabular}

\footnotetext{
*Age conversion using Lebeau [58] and the online access tool Available from: http://www.pedigree.com/all-things-dog/ dog-age-calculator/. **Events common to both species as described by Lebeau [58]. ***Only cases of known age are included (values in brackets are the age-specific rates per 100,000)
}

in dogs, no staging was done on any of the morphological diagnoses. The proportional distribution of diagnostic methods for the dog cancers were necropsy/post-mortem $(41.7 \%)$, followed by clinical only $(25.3 \%)$, histology primary $(14.7 \%)$, laboratory tests $(9.0 \%)$, surgery/autopsy $(8.4 \%)$, cytology
$(0.5 \%)$, and clinical investigation $(0.3 \%)$. The data quality indicators for the human records from the Nairobi Cancer Registry showed that $98.5 \%$ of the records were valid for analysis (excluding those with unknown age), $83.6 \%$ were confirmed through laboratory analysis, $15.6 \%$ diagnosed through clinical 

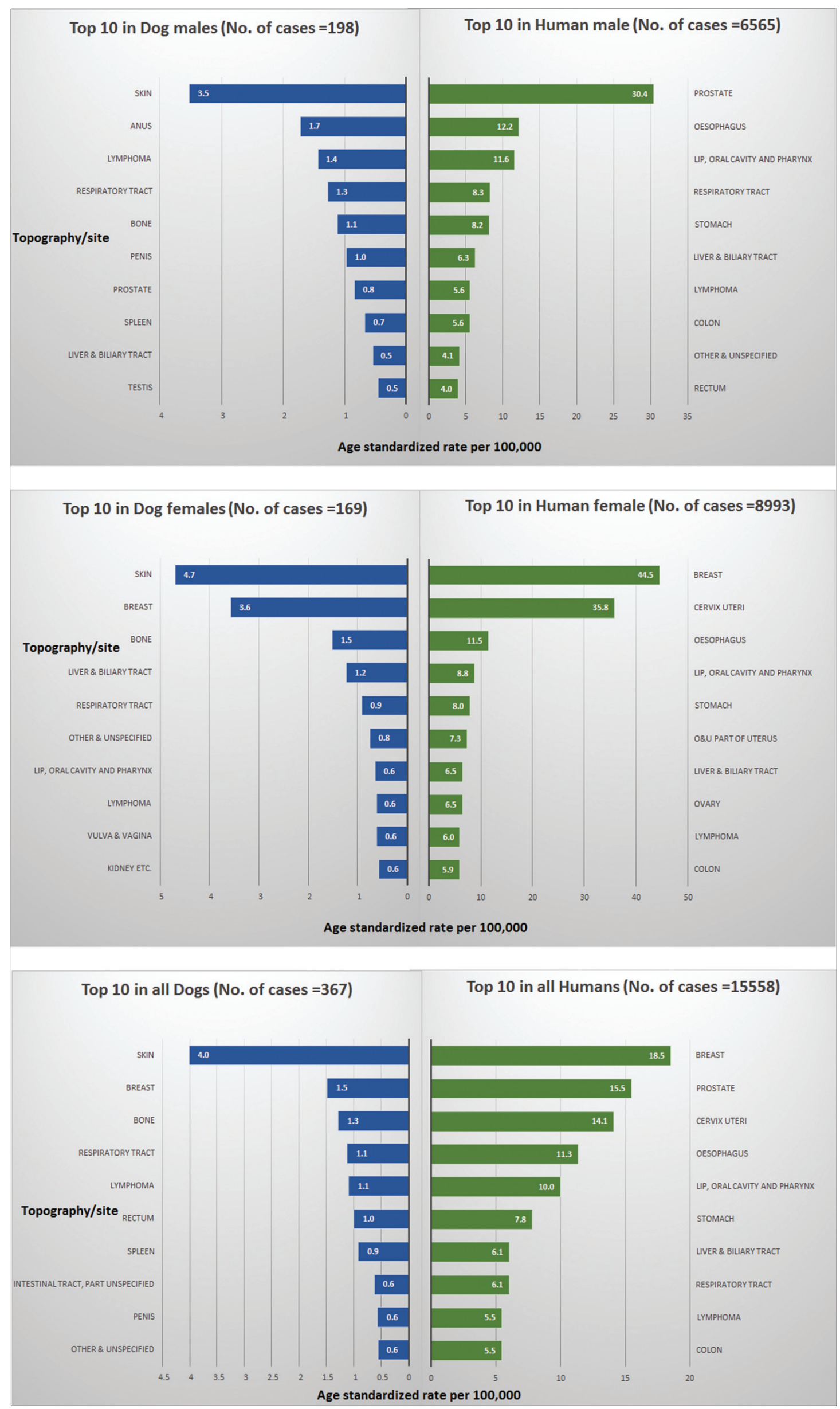

Figure-3: Top 10 most common cancers in male and female humans and dogs in Nairobi (2002-2012). 


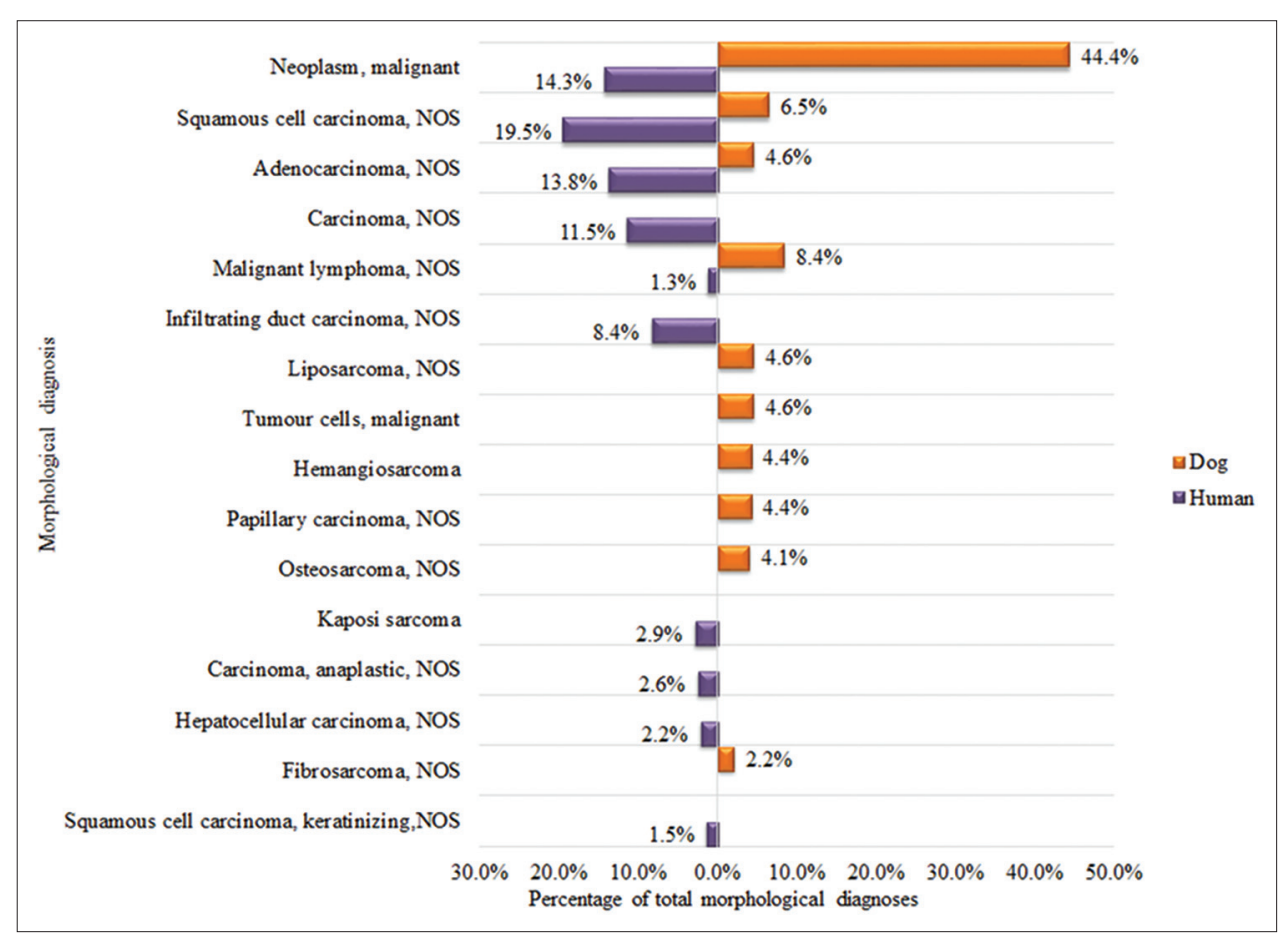

Figure-4: Common morphological diagnoses of cancer in humans and dogs in Nairobi (2002-2012).

investigation, and only $0.8 \%$ were diagnosed through the certificate of death.

\section{Discussion}

\section{Dataset and methods}

The difference between the number of cancer cases retrieved for the human dataset $(n=15,558)$ compared to dogs $(n=367)$ could be explained by a wider institutional coverage of the human dataset (27 facilities) [22] as compared to the canine data (7 facilities). However, the dog and human data do provide a comparative basis of certain cancer sites since they take into account the size and characteristics of the population at risk. Further, the human and dog data collection did not only rely on pathology departments but also traced clinically diagnosed cases.

Due to lack of dog population numbers for Nairobi County, estimates were calculated using the published human:dog ratio of 4.1:1 [27]. This ratio 4.1:1 was preferred since it represents an urban population setting that is comparable to the study population, i.e., Kisumu and Nairobi are both urban cities in Kenya. The lack of pet animal demographic data is a common phenomenon across the entire country. There is, therefore, need for the government of Kenya to integrate small animals (dogs and cats) into the National Census, which will also support other intervention strategies such as rabies control that require knowledge of the dog population. We further suggest that developing a World Standard Population for dogs could complement future comparative oncology studies, especially when it comes to comparing ASRs; this is based on the fact that most studies that are published and which we have referenced [13,30-32] (excluding Dobson et al. [33]) that investigated cancer in dogs and cats reported the percentage of cases rather than ASRs. This, therefore, makes it difficult to compare accurately the cancer incidence between different populations [29].

\section{Trend of cancer}

The increasing number of cancer cases, with advancing in age, in both humans and dogs in Nairobi is consistent with reports on the occurrence of various cancers from other parts of the world [34] and as also reported by other studies in California-Davis [13], ItalyGenoa [31], and in the UK [33]. The increasing number of cancer cases could be attributed to: An actual increase in cancer cases in both humans and dogs; an increase in the population at risk of developing cancers; an increasing proportion of facilities offering veterinary and human medical [35] services, or an increased awareness level and interest to undertake diagnostic and therapeutic options for cancer [1]. Further, this increase can be as a result of the changes taking place in Kenya such as socioeconomic development, accessibility to regional and international markets, demographic changes, and rapid urbanization and modernization [35]. These factors result to an accelerated exposure to cancer risk factors such as lifestyle change, access to unhealthy foods (high fat and high salt) and consumer products for both human and dog populations.

It was not possible to explain why there was a depressed number of cases in the year 2007 while, for the year 2009, it could be attributable to the postelection chaos that could have resulted in a low attendance to health facilities.

\section{Cancer incidence by gender}

The number of cancer cases in humans and dogs was almost equally distributed in both genders, which 
contrast findings by Merlo et al. [31], who found a 3 -fold higher incidence in females than male dogs. The slightly higher cancer cases in human females could be attributed to the higher mammary and cervical cancers, at the same time the publicity for cancer screening among females in Nairobi may have contributed to the higher frequency in the number of cases, rather than the occurrence of cancer. Another plausible reason could be that females have a higher tendency of health-seeking behavior as compared to males. The occurrence of a higher age-standardized cancer rate among female dogs although their population and cancer cases were lower as compared to male dogs, could infer that female dogs could be having a higher predisposition to cancer or the frequency of cancer occurrence in females is higher as compared to males. Future studies are needed to explain the causal mechanisms for this phenomenon.

\section{Age and cancer}

The number of cancer cases in both humans and dogs was clearly associated with age and also as observed by Dobson et al. [33] in the UK, Merlo et al. [31] in Italy, and the 2014 World Cancer Report [34]. In humans, cancer cases peaked at the 40-44 age group in women and at $75+$ age group in men, which was a similar finding from the World Cancer Report [34] in sub-Saharan Africa. In female dogs, cancer cases peaked at the 11-12 age group and the +15 age group in males, similar to findings by Dobson et al., 2002 ( $>9$ years) [33], Merlo et al., 2008 (>9-11 years) [31], and slightly with Grüntzig et al., 2015 (between 5 and 10 years) [32].

It is significant to note that cancer peaks later in both human and dog males as compared to the females, this can possibly be explained by the earlier age onset of breast and cervical cancers in females and later age onset of prostate cancers in males [34]. It is also evident that dogs are frequently affected by cancers between the age of $>9$ years similar to findings by Dorn et al. [13], which is much earlier than in man [14]. This may potentially facilitate the detection of hazards and risk factors for cancer earlier in dogs than in humans.

\section{Breed predisposition to cancer}

The overrepresentation of the GSD breed and crossbreed is similar to findings by Grüntzig et al., 2015 [32]; this finding could be because they are common utility breeds and commonly used for security purposes in most developing nations, Kenya inclusive. The distribution of most of the cancers by both topography and morphology was more related to the number of cases reported than the dog breed, and therefore, the effect of breed on the cancer cases in this study was generally not clear, but the GSD was differentially predisposed to the hemangiosarcoma while the Labrador to the mast cell tumor, but this could not conclusively be established as compared to the study by Dobson et al. [36].
The most common cancers by topography in both humans and in dogs

Despite the short period of study (2002-2012), the data collected so far does show consistency and specific contrasts with reports on the occurrence of various cancers from other parts of the world [34], Africa (Supplementary Material-2), and other dog and comparative research studies (Supplementary Material-3).

In this study, we have observed that there are common cancers that affect both humans and dogs and some disproportionately affecting a certain gender. This does infer a possibility of common environmental carcinogens or risk factors. For example, liver cancers (probably as a result of aflatoxins [37], hepatitis B and $\mathrm{C}$ infection $[38,39]$ or indiscriminate alcohol consumption $[22,40]$; respiratory cancers (probably due to chronic smoking in humans [41], passive smoking and other environmental exposures, e.g. diesel exhaust, arsenic in water, etc., for both), lymphoma (as a result of viral carcinogen [42], lifestyle charges and chemicals), and age/hormonal/lifestyle change/urbanization [43] in case of prostate [44] and breast/mammary gland cancers [45-47]. This does show a potential for future studies (in Kenya or Africa) to use dogs as models to study prostate, breast/mammary gland, and lymphoma cancers and as sentinels for liver and respiratory cancers. Several studies have already shown this possibility of using dogs as sentinels [16-20] and models $[7,15]$ for studying human cancers.

\section{Tumor diagnostic approaches}

At the tumor level, the most common individual morphological tumor diagnosis in humans and dogs were approximately as one would expect based on estimates from previous studies in dogs [48] and humans [34]. A commonality in both humans and dogs in regard to morphological diagnosis and staging in this study was the high number of ICD-O code 8000 , and the unknown staging (88.7\%) in humans and with no staging in dogs. In dogs, this could possibly be explained by findings on diagnostic approaches, where the detection and diagnosis of tumors vary according to objective difficulties and methodologic difference among veterinary clinics as also noted by Brønden et al. [7]. Contrary, in humans, most of the diagnoses are confirmed through laboratory techniques, which is commendable. Irrespective of this, it is crucial to remember that very few people in developing countries (including Kenya) can manage the cost of cancer diagnosis (not mentioning treatment), and therefore, this informs us that there are still many cancer cases that are not captured or reported in this study. Future studies should focus on bridging this gap to identify the unreported cases through community-based cancer studies, so as to determine the true burden of cancer.

In this study, most tumors in dogs were diagnosed at postmortem ( $41.7 \%$ of all cases) and clinical only $(25.3 \%$ of all cases), with laboratory methods contributing (32.9\% of all cases). The fact that most 
cases were diagnosed as deceased shows that there is a high mortality rate of canine patients diagnosed with cancer although the causes of death may not be as a result of these cancers. Cancer diagnosis involving a combination of careful clinical assessment and diagnostic investigations is the first step to cancer management, but in a developing country like Kenya most of the cancer diagnostic methods are rare or limited and also the cost involved is high, partly explaining the diagnostic outcome.

\section{Conclusion and Recommendations}

An 11-year comparative study is relatively a short period for comments on general trends for disease, including cancer. However, despite the short period, data collected so far does show a consistency and specific contrasts with reports on the occurrence of various cancers from other parts of the world, region, and other comparative research studies in both humans and dogs. We would also like to highlight that cancer registration is a difficult enterprise in Africa, faced by a number of shortcomings making the distribution of most cancer registries in Africa confined to the urban populations, Mali [49], Guinea [38], Zimbabwe [50], Ivory coast [51], Uganda [52], Malawi [53], except the Gambia [54] that has a cancer registry with a national coverage [54].

Perhaps the most important contribution that this study makes is providing for the first time from a developing nation, Kenya, comparative aspects of cancers in dogs and humans in the same geographical area. From the results, it is clear that more comparative research adopting integrative and SMART One Health approaches are required. Since many dogs in Kenya and many parts of Africa share with humans common environments and lifestyle and since cancer in both has a clinical and histological similarity, the potential for using dogs as models and sentinels is present. At the same time, dog breeding over time has resulted in clear breed-predisposition to certain cancer types. This implies both an excellent model for genetic risk factors in cancer development and also possibility to investigate protective genotypes as well which, in fact, could explain higher and lesser predisposition to respond to a certain environmental carcinogen.

As we have noted in this study, dogs are frequently affected by cancers at a much earlier time than man similar to findings by Dorn et al. [13]; this may potentially facilitate detection of risks and hazards earlier in dogs than humans. Future sentinel studies should, therefore, be planned to assess this possibility. This can only be achieved with well-established "comparative" cancer registries that provide accurate data to allow spatial identification of differences in low and high human and/or dog risk populations and thus providing clues into the etiology of cancer. More importantly, there is need to strengthen the existing human cancer registries since as of now cancer is one of the primary objectives for African governments [55]. There is need for the veterinary surgeons and pathologists in Kenya to start thinking of developing a cancer surveillance system which may be integrated to the human cancer registry. We also recommend and encourage that all cancer diagnoses, especially staging of cancer in dogs, to be reported using internationally standardized formats, which will provide a strong basis for future comparative research. However, there are still challenges that have to be overcome, such as the stigma driven by traditional beliefs which prevent people from seeking screening and diagnosis and limited resources, especially the crucial resource of knowledge.

In conclusion, we reiterate that Africa can win the battle against cancer through collaborative public health action through the One Health movement [56], and through innovations and training in comparative oncology research through complementary intra-Africa and North-South collaborations.

\section{Authors' Contributions}

NKM conducted the research and actively prepared the manuscript. NKM and REM designed the work. REM and RAK participated in the manuscript preparation and advice during the research work. All the authors read and approved the final manuscript.

\section{Acknowledgments}

The authors are most grateful to the institutions which participated in this study by providing access to data and for considerable assistance received from the staff of the veterinary clinics and the Nairobi Cancer Registry during the study. We also extend our sincere appreciation to Dr. Neil Anderson from the Royal (Dick) School of Veterinary Studies for his valuable input and technical editing of the first draft of the manuscript.

\section{Competing Interests}

The authors declare that they have no competing interests.

\section{References}

1. Paoloni MC, Khanna C. Comparative oncology today. Vet Clin North Am Small Anim Pract 2007;37:1023-32; v.

2. Weintraub A. Heal: The vital Role of Dogs in the Search for Cancer Cures. Canada: ECW Press; 2015.

3. Zinsstag J, Waltner-Toews D, Tanner M. Theoretical issues of one health. In: Zinsstag J, Schelling E, Waltner-Toews D, Whittaker M, Tanner M, editors. One Health: The Theory and Practice of Integrated Health Approaches. Wallingford, UK: CABI International; 2015. p. 16.

4. Kenya Medical Research Institute. Launch of the National Cancer Registry Programme, in the $6^{\text {th }}$ KEMRI Annual Scientific and Health (KASH) Conference. Nairobi, Kenya: Kenya Medical Research Institute (KEMRI): The Boma; 2016. p. 12.

5. Popat K, McQueen K, Feeley TW. The global burden of cancer. Best Pract Res Clin Anaesthesiol 2013;27:399-408.

6. Bonnett BN, Egenvall A, Olson P, Hedhammar A. Mortality in insured Swedish dogs: Rates and causes of death in various breeds. Vet Rec 1997;141:40-4. 
7. Brønden LB, Flagstad A, Kristensen AT. Veterinary cancer registries in companion animal cancer: A review. Vet Comp Oncol 2007;5:133-44.

8. Proschowsky HF, Rugbjerg H, Ersboll AK. Mortality of purebred and mixed-breed dogs in Denmark. Prev Vet Med 2003;58:63-74.

9. World Health Organisation. Global Status Report on Noncommunicable Diseases 2014. Geneva: World Health Organisation; 2014. p. 298.

10. Government of Kenya, National Cancer Control Strategy 2011-2016. Ministry of Public Health and Sanitation and Ministry of Medical Services Kenya; 2011. p. 38.

11. Government of Kenya, Policy Brief on the Situational Analysis of Cancer in Kenya. Parliamentary Service Commission-Department of Research, Government Printer: Nairobi, Kenya; 2011. p. 4-6.

12. Mack GS. Cancer researchers usher in dog days of medicine. Nat Med 2005;11:1018.

13. Dorn CR, Taylor DO, Frye FL, Hibbard HH. Survey of animal neoplasms in Alameda and Contra Costa Counties, California. I. Methodology and description of cases. J Natl Cancer Inst 1968;40:295-305.

14. Thrusfield M. Companion animal epidemiology: Its contribution to human medicine. Proceedings of the $5^{\text {th }}$ International Symposium on Veterinary Epidemiology and Economics. Copenhagen, Denmark: Acta Veterinaria Scandinavica. Supplementum, 84. 1988. p. 57-65.

15. Ostrander EA, Giger U, Lindblad-toh K. The Dog and its Genome. New York: Cold Spring Harbor Laboratory Press; 2006.

16. Glickman LT, Domanski LM, Maguire TG, Dubielzig RR, Churg A. Mesothelioma in pet dogs associated with exposure of their owners to asbestos. Environ Res 1983;32:305-13.

17. Hayes HM Jr, Hoover R, Tarone RE. Bladder cancer in pet dogs: A sentinel for environmental cancer? Am J Epidemiol 1981;114:229-33.

18. Ostrowski SR. Sentinel animals (Dogs) as predictors of childhood exposure to environmental lead contamination: Observations on preliminary results. In: Sandhu S, Lower WR, de Serres FJ, Suk WA, Tice RR, editors. In Situ Evaluation of Biological Hazards of Environmental Pollutants. US: Springer; 1990. p. 145-50.

19. Reif JS, Dunn K, Ogilvie GK, Harris CK. Passive smoking and canine lung cancer risk. Am J Epidemiol 1992 1;135:234-9.

20. Reif JS, Rhodes WH, Cohen D. Canine pulmonary disease and the urban environment. I. The validity of radiographic examination for estimating the prevalence of pulmonary disease. Arch Environ Health 1970;20:676-83.

21. Backer LC, Grindem CB, Corbett WT, Cullins L, Hunter JL. Pet dogs as sentinels for environmental contamination. Sci Total Environ 2001;274:161-9.

22. Kenya Medical Research Institute. In: Mutuma G, Korir A, editors. Kenya Nairobi Cancer Incidence Report, 2000-2002. Nairobi: Kenya Medical Research Institute (KEMRI); 2006.

23. Korir A, Okerosi N, Victor R, Mutuma G, Parkin M. Incidence of cancer in Nairobi, Kenya (2004-2008). Int J Cancer 2015;137:2053-9.

24. Kenya National Bureau of Statistics. In: C.B.O. Statistics, editor. The 2009 Kenya Population and Housing Census. Nairobi: Kenya National Bureau of Statistics; 2010. p. 28.

25. MacLennan R. Items of patient information which may be collected by registries. In: Jensen OM, Parkin DM, MacLennan R, Muir CS, Skeet RG, editors. Cancer Registration: Principles and Methods. Lyon: International Agency for Research on Cancer; 1991. p. 43-63.

26. Kenya National Bureau of Statistics. In: C.B.O. Statistics, editor. The 1999 Kenya Population and Housing Census. Nairobi: Kenya National Bureau of Statistics; 2001. p. xxxiii.

27. Muriuki J, Thaiya A, Mbugua SW, Kitaa J. Dog populations and dog-keeping practises in relation to raies control in Kisumu and Siaya Counties, Kenya. Int J Agric Sci Vet Med 2016;4:90-100.

28. Thrusfield M. Demographic characteristics of the canine and feline populations of the UK in 1986. J Small Anim Pract 1989;30:76-80.

29. Boyle P, Parkin DM. Statistical methods for registries. In: Jensen OM, Parkin DM, MacLennan R, Muir CS, Skeet RG, editors. Cancer Registration: Principles and Methods. Lyon, France International Agency for Research on Cancer; 1991. p. $126-58$.

30. Gamlem H, Nordstoga K, Glattre E. Canine neoplasia - Introductory paper. APHIMS Suppl 2008;125:5-18.

31. Merlo DF, Rossi L, Pellegrino C, Ceppi M, Cardellino U, Capurro $\mathrm{C}$, et al. Cancer incidence in pet dogs: Findings of the Animal Tumor Registry of Genoa, Italy. J Vet Intern Med 2008;22:976-84.

32. Grüntzig K, Graf R, Hässig M, Welle M, Meier D, Lott G, et al. The Swiss canine cancer registry: A retrospective study on the occurrence of tumours in dogs in Switzerland from 1955 to 2008. J Comp Pathol 2015;152:161-71.

33. Dobson JM, Samuel S, Milstein H, Rogers K, Wood JL. Canine neoplasia in the UK: Estimates of incidence rates from a population of insured dogs. J Small Anim Pract 2002;43:240-6.

34. International Agency for Research on Cancer. In: Stewart BW, Wild CP, editors. World Cancer Report 2014. Lyon, France: International Agency for Research on Cancer; 2014. p. 627.

35. Kenya National Bureau of Statistics. In: C.B.O. Statistics, editor. Kenya Facts and Figures 2015. Nairobi: Kenya National Bureau of Statistics; 2015.

36. Dobson JM. Breed-predispositions to cancer in pedigree dogs. ISRN Vet Sci 2013;2013:941275.

37. Meuten DJ. Tumours in Domestic Animals. $4^{\text {th }}$ ed. Ames, Iowa: Iowa State Press; 2002.

38. Koulibaly M, Kabba IS, Cissé A, Diallo SB, Diallo MB, Keita N, et al. Cancer incidence in Conakry, Guinea: First results from the cancer registry 1992-1995. Int J Cancer 1997;70:39-45

39. Pisani P, Parkin DM, Muñoz N, Ferlay J. Cancer and infection: Estimates of the attributable fraction in 1990. Cancer Epidemiol Biomarkers Prev 1997;6:387-400.

40. International Agency for Research on Cancer, Alcohol Drinking. Monographs on the Evaluation of Carcinogenic Risks to Humans. Vol. 44. Lyons: IARC Press; 1988.

41. Ezzati M, Lopez AD. Estimates of global mortality attributable to smoking in 2000. Lancet 2003;362:847-52.

42. International Agency for Research on Cancer, Human Immunodeficiency Viruses and Human T-cell Lymphotrophic Viruses. IARC Monographs on the Evaluation of Carcinogenic Risks to Humans. Vol. 67. Lyon: IARC Press; 1996.

43. Steyn K, Damasceno A. Lifestyle and related risk factors for chronic diseases. In: Jamison DT, Feachem RG, Makgoba MW, Bos ER, Baingana FK, Hofman KJ, et al., editors. Disease and Mortality in Sub-Saharan Africa. Washington, DC: World Bank; 2006. p. 247-65.

44. Waters DJ, Patronek GJ, Bostwick DG, Glickman LT. Comparing the age at prostate cancer diagnosis in humans and dogs. J Natl Cancer Inst 1996;88:1686-7.

45. Bostock DE. Canine and feline mammary neoplasms. Br Vet J 1986;142:506-15.

46. Brearley MJ. Mammary gland tumours in the dog. In Pract 1989;11:248-53.

47. Baba AI, Câtoi C. Mamary gland tumours. In: Comparative Oncology. Bucharest: The Publishing House of the Romanian Academy; 2007.

48. Priester WA, Mckay FW. Occurrence of tumours in domestic animals. Data from 12 United States and Canadian colleges of veterinary medicine. J Natl Cancer Inst 1971;47:1-210.

49. Bayo S, Parkin DM, Koumaré AK, Diallo AN, Ba T, 
Soumaré S, et al. Cancer in Mali, 1987-1988. Int J Cancer 1990;45:679-84.

50. Chokunonga E, Levy LM, Bassett MT, Mauchaza BG, Thomas DB, Parkin DM. Cancer incidence in the African population of Harare, Zimbabwe: Second results from the cancer registry 1993-1995. Int J Cancer 2000;85:54-9.

51. Echimane AK, Ahnoux AA, Adoubi I, Hien S, M'Bra K, D'Horpock A, et al. Cancer incidence in Abidjan, Ivory Coast: First results from the cancer registry, 1995-1997. Cancer 2000;89:653-63.

52. Wabinga HR, Parkin DM, Wabwire-Mangen F, Nambooze S. Trends in cancer incidence in Kyadondo County, Uganda, 1960-1997. Br J Cancer 2000;82:1585-92.

53. Banda LT, Parkin DM, Dzamalala CP, Liomba NG. Cancer incidence in Blantyre, Malawi 1994-1998. Trop Med Int
Health 2001;6:296-304.

54. Bah E, Parkin DM, Hall AJ, Whittle H. Cancer in the Gambia: 1988-1997. Br J Cancer 2001;84:1707-24.

55. SCCA, $9^{\text {th }}$ Stop Cervical, Breast $\&$ Prostate Cancer in Africa: Declaration, in Investing to Save Lives: The Role of Public \& Private Sector Partnerships. Nairobi, Kenya; 2015.

56. Lueddeke G. Global Population Health and Well-Being in the $21^{\text {st }}$ Century: Toward New Paradigms, Policy, and Practice. New York: Springer Publishing Company, LLC; 2015. p. 508

57. International Agency for Research on Cancer. International Classification of Diseases for Oncology. $3^{\text {rd }}$ ed., Vol. 3. Geneva: World Health Organization; 2013.

58. Lebeau A. The age of the dog and that of man. Statistical test on canine mortality. B Acad Vet France 1953;26:229-32.

$* * * * * * * *$

\section{Supplementary Materials}

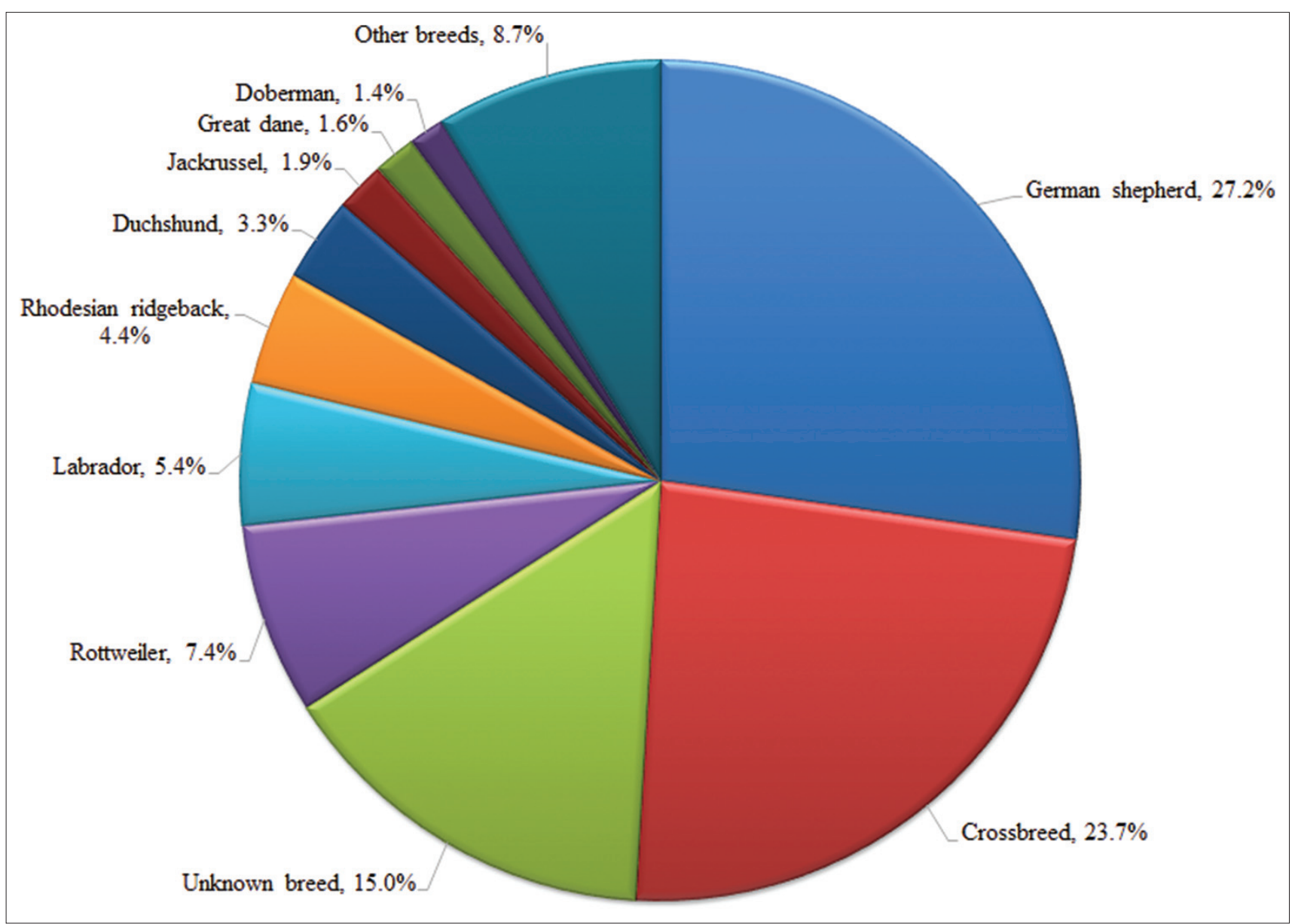

Supplementary Material 1: Dog breed distribution in Nairobi (2002-2012). 
Supplementary Material-2: Top five most common cancers in 10 human registries in Africa in terms of their incidence.

\begin{tabular}{|c|c|c|c|c|c|c|c|}
\hline Rank & $\mathrm{CR}^{* 1}[1]$ & $\mathrm{CR} * 2[1]$ & $\mathrm{CR} * 3[1]$ & $\mathrm{CR} *[1]$ & $\mathrm{CR} * 5[1]$ & $\mathrm{CR} * 6[2]$ & $\mathrm{CR} * 7[3]$ \\
\hline \multirow[t]{2}{*}{1} & M: Liver & M: Lung & M: Liver & M: Liver & M: Liver & M: Liver & M: Liver \\
\hline & F: Cervix & F: Cervix & F: Cervix & F: Liver & F: Cervix & F: Cervix & F: Cervix \\
\hline \multirow[t]{2}{*}{2} & M: NHL & M: Liver & M: Prostate & M: Stomach & M: Stomach & M: Prostate & M: Esophagus \\
\hline & F: Breast & F: Liver & F: Breast & F: Cervix & F: Liver & F: Liver & F: Breast \\
\hline \multirow[t]{2}{*}{3} & M: Prostate & M: Prostate & M: Stomach & M: NHL & M: Bladder & M: Stomach & M: Prostate \\
\hline & F: NHL & F: Breast & F: Liver & F: Breast & F: Stomach & F: Breast & F: Liver \\
\hline \multirow[t]{2}{*}{4} & M: Stomach & M: Bladder & M: Bladder & M: Prostate & M: Lung & M: Lung & M: Kaposi's \\
\hline & F: Stomach & F: Stomach & $\begin{array}{l}\text { F: Bladder and } \\
\text { colorectum }\end{array}$ & F: Stomach & F: Breast & F: Stomach & F: Stomach \\
\hline \multirow[t]{2}{*}{5} & M: Leukemia & M: Stomach & M: Colorectum & M: Lung & M: Prostate & M: Bladder & M: Lung \\
\hline & $\begin{array}{l}\text { F: Liver AND } \\
\text { leukemia }\end{array}$ & F: Bladder & $\mathrm{F}: \mathrm{NHL}$ & $\mathrm{F}: \mathrm{NHL}$ & F: Bladder & F: Ovary & F: Bladder \\
\hline Rank & $\mathrm{CR} * 8$ & CR*9 [4] & $\mathrm{CR} * 10$ & $\mathrm{CR} * 11$ & $\mathrm{CR} * 12[7]$ & $\mathrm{CR} * 13[8]$ & $\mathrm{CR} * 14[9]$ \\
\hline \multirow[t]{2}{*}{1} & M: Kaposi's & M: Prostate & M: Kaposi's & M: Liver & M: Kaposi's & M: Prostate & M: Prostate \\
\hline & F: Cervix & F: Cervix & F: Cervix & F: Cervix & $\begin{array}{l}\text { sarcoma } \\
\text { F: Cervix }\end{array}$ & F: Breast & F: Breast \\
\hline \multirow[t]{2}{*}{2} & M: Liver & M: Liver & M: Prostate & M: Lung & M: Esophagus & M: Esophagus & M: Mouth \\
\hline & F: Breast & F: Breast & $\begin{array}{c}\text { F: Breast and } \\
\text { Kaposi's } \\
\text { sarcoma }\end{array}$ & F: Liver & $\begin{array}{l}\text { F: Kaposi's } \\
\text { sarcoma }\end{array}$ & F: Cervix & F: Cervix uteri \\
\hline \multirow[t]{2}{*}{3} & M: Prostate & M: Lung & M: Esophagus & M: Prostate & M: Prostate & M: Colorectal & M: Esophagus \\
\hline & $\begin{aligned} \text { F: Kaposi's } \\
\text { sarcoma }\end{aligned}$ & F: Liver & F: Colorectum & F: Breast & F: Breast & F:Esophagus & F: Esophagus \\
\hline \multirow[t]{2}{*}{4} & M: Esophagus & M: Stomach & M: Stomach & $\mathrm{M}: \mathrm{NHL}$ & M: Liver & M: Stomach & M: Stomach \\
\hline & F: Liver & F: Stomach & F: Liver & F: Corpus Uteri & $\mathrm{F}: \mathrm{NHL}$ & F: Colorectal & F: Mouth \\
\hline \multirow[t]{2}{*}{5} & M: Lung & M: NHL & M: NHL & M: Stomach & M: Bladder and & M: Oral cavity & M: Respiratory \\
\hline & F: Stomach & F: Ovary & $\mathrm{F}: \mathrm{NHL}$ & F: Stomach & $\begin{array}{c}\text { NHL } \\
\text { F: Thyroid }\end{array}$ & F: Stomach & F: Stomach \\
\hline
\end{tabular}

$\mathrm{CR}^{* 1}=$ Ibadan, Nigeria 1960-69, CR*2=Bulawayo, Zimbabwe 1968-72, CR*3=Dakar, Senegal, 1969-74, CR*4=Gambia 1986-88, CR*5=Bamako, Mali 1987-88, CR*6=Guinea, Conakry 1992-95, CR*7=Harare, Zimbabwe 1990-92, $\mathrm{CR}^{* 8}=$ Harare, Zimbabwe 1993-95, CR*9=Abidjan, Ivory Coast 1995-1997, CR*10=Kampala, Uganda 1995-1997, $\mathrm{CR}^{* 11}=$ Gambia, 1988-97, CR*12=Blantyre, Malawi 1994-1998, CR*13=Nairobi, Kenya, 2004-2008. CR=Cancer registry, $\mathrm{NHL}=$ Non-Hodgkin Iymphoma, $\mathrm{M}=$ Male, $\mathrm{F}=$ Female

\section{References}

1. Bayo S, Parkin DM, Koumaré AK, Diallo AN, Ba T, Soumaré S, et al. Cancer in Mali, 1987-1988. Int J Cancer 1990;45:679-84.

2. Koulibaly M, Kabba IS, Cissé A, Diallo SB, Diallo MB, Keita N, et al. Cancer incidence in Conakry, Guinea: First results from the cancer registry 1992-1995. Int J Cancer 1997;70:9-45.

3. Chokunonga E, Levy LM, Bassett MT, Mauchaza BG, Thomas DB, Parkin DM. Cancer incidence in the African population of Harare, Zimbabwe: Second results from the cancer registry 1993-1995. Int J Cancer 2000;85:54-9.

4. Echimane AK, Ahnoux AA, Adoubi I, Hien S, M'Bra K, D'Horpock A, et al. Cancer incidence in Abidjan, ivory coast: First results from the cancer registry, 1995-1997. Cancer 2000;89:653-63.

5. Wabinga HR, Parkin DM, Wabwire-Mangen F, Nambooze S. Trends in cancer incidence in Kyadondo County, Uganda, $1960-1997$. Br J Cancer 2000;82:1585-92.

6. $\quad$ Bah E, Parkin DM, Hall AJ, Jack AD, Whittle H. Cancer in the Gambia: 1988-1997. Br J Cancer 2001;84:1707-24.

7. Banda LT, Parkin DM, Dzamalala CP, Liomba NG. Cancer incidence in Blantyre, Malawi 1994-1998. Trop Med Int Health 2001;6:296-304.

8. Korir A, Okerosi N, Ronoh V, Mutuma G, Parkin M. Incidence of cancer in Nairobi, Kenya (2004-2008). Int J Cancer 2015;137:2053-9.

9. Forman D, Bray F, Brewster DH, Gombe C, Kohler B, Piñeros M, et al. Cancer Incidence in Five Continents. Vol. X. (Electronic Version). Lyon: International Agency for Research on Cancer; 2013. 
Supplementary Material-3: The top five most common cancers in six dog cancer registries in terms of percent of total cases.

\begin{tabular}{|c|c|c|c|c|c|c|}
\hline Rank & $\mathrm{CR} * 1[1]$ & $\mathrm{CR} * 2[2]$ & $\mathrm{CR} * 3[3]$ & $\mathrm{CR} * 4[4]$ & $\mathrm{CR} * 5[5]$ & $\mathrm{CR} * 6$ \\
\hline 1 & $\begin{array}{l}\text { M: Skin } \\
\text { F: Mammary gland }\end{array}$ & $\begin{array}{l}\text { M: Skin } \\
\text { F: Mammary } \\
\text { gland }\end{array}$ & $\begin{array}{l}\text { Skin and soft } \\
\text { tissue }\end{array}$ & $\begin{array}{l}\text { M: NHL } \\
\text { F: Mammary gland }\end{array}$ & Skin & $\begin{array}{l}\text { M: Skin } \\
\text { F: Skin }\end{array}$ \\
\hline 2 & $\begin{array}{l}\text { M: Connective } \\
\text { tissue } \\
\text { F: Skin }\end{array}$ & $\begin{array}{l}\text { M: Testis } \\
\text { F: Oral cavity }\end{array}$ & Alimentary & $\begin{array}{l}\text { M: Skin } \\
\text { F: NHL }\end{array}$ & Mammary gland & $\begin{array}{l}\text { M: Anus } \\
\text { F: Breast }\end{array}$ \\
\hline 3 & $\begin{array}{l}\text { M: Testis } \\
\text { F: Connective } \\
\text { tissue }\end{array}$ & $\begin{array}{l}\text { M: Oral cavity } \\
\text { F: Vagina/vulva }\end{array}$ & Mammary & $\begin{array}{l}\text { M: Male genital } \\
\text { organs } \\
\text { F: Connective and soft } \\
\text { tissue }\end{array}$ & Soft tissue & $\begin{array}{l}\text { M: Lymphoma } \\
\text { F: Bone }\end{array}$ \\
\hline 4 & $\begin{array}{l}\text { M: Mouth and } \\
\text { pharynx } \\
\text { F: Lymphosarcoma }\end{array}$ & $\begin{array}{l}\text { M: Eye } \\
\text { F: Ovary }\end{array}$ & Urogenital & $\begin{array}{l}\text { M: Connective and } \\
\text { soft tissue } \\
\text { F: Skin }\end{array}$ & Gastrointestinal & $\begin{array}{l}\text { M: Respiratory } \\
\text { tract } \\
\text { F: Liver and biliary } \\
\text { tract }\end{array}$ \\
\hline 5 & $\begin{array}{l}\text { M: Lymphosarcoma } \\
\text { F: Mouth and } \\
\text { pharynx }\end{array}$ & $\begin{array}{l}\text { M: Spleen } \\
\text { F: Eye }\end{array}$ & Lymphoid & $\begin{array}{l}\text { M: Lip, oral cavity, } \\
\text { and pharynx } \\
\text { F: Digestive organs } \\
\text { and peritoneum }\end{array}$ & $\begin{array}{l}\text { Male sexual } \\
\text { organs }\end{array}$ & $\begin{array}{l}\text { M: Bone } \\
\text { F: Respiratory } \\
\text { tract }\end{array}$ \\
\hline
\end{tabular}

$\mathrm{CR}^{* 1}=$ Alamada and Contra Costa, California 1963-1966, CR*2=Norwegian Canine Cancer Project, 1990-1998, CR*3 $=$ UK, 1997-1998, CR*4=Genoa, Italy, 1985-2002, CR*5: Switzerland, 1955-2008, CR*6: Nairobi, 2002-2012. CR=Cancer registry, $\mathrm{NHL}=$ Non-Hodgkin lymphoma, $\mathrm{M}=$ Male, $\mathrm{F}=$ Female

\section{References}

1. Dorn CR, Taylor DO, Frye FL, Hibbard HH. Survey of animal neoplasms in Alameda and Contra Costa Counties, California. I. Methodology and description of cases. J Natl Cancer Inst 1968;40:295-305.

2. Gamlem H, Nordstoga K, Glattre E. Canine neoplasia - Introductory paper. APMIS Suppl 2008;5-18.

3. Dobson JM, Samuel S, Milstein H, Rogers K, Wood JL. Canine neoplasia in the UK: Estimates of incidence rates from a population of insured dogs. J Small Anim Pract 2002;43:240-6.

4. Merlo DF, Rossi L, Pellegrino C, Ceppi M, Cardellino U, Capurro C, et al. Cancer incidence in pet dogs: Findings of the Animal Tumor Registry of Genoa, Italy. J Vet Intern Med 2008;22:976-84.

5. Gruntzig K, Graf R, Hässig M, Welle M, Meier D, Lott G, et al. The Swiss Canine cancer registry: A retrospective study on the occurrence of tumours in dogs in Switzerland from 1955 to 2008. J Comp Pathol 2015;152(2-3):161-71. 